\title{
PENGARUH SIRKUIT TRAINING AWAL AKHIR LATIHAN TEKNIK TERHADAP KARDIORESPIRASI, POWER, SMASH, PASSING BAWAH ATLET BOLA VOLI
}

\author{
THE EFFECT OF TRAINING CIRCUIT THE BEGINNING THE END OF TECHNICAL \\ EXERCISES ON THE CARDIORESPIRATION, POWER, SMASH, UNDERHAND PASSING \\ SKILLS OF VOLLEYBALL
}

\author{
Hendri Permana, Suharjana \\ SMAN 1 Wedi, Universitas Negeri Yogyakarta \\ hendripermana1979@yahoo.co.id, suharjana_fikuny@yahoo.com
}

\begin{abstract}
Abstrak
Penelitian ini bertujuan untuk mengetahui pengaruh latihan sirkuit training di awal latihan dan di akhir latihan teknik terhadap kemampuan kardiorespirasi, power, keterampilan smash dan passing bawah pada atlet bola voli klub Yuso Sleman. Penelitian ini adalah penelitian eksperimen dengan desain penelitian Prettest-Posttest Group Design. Populasi penelitian adalah atlet bola voli putra klub Yuso Sleman. Sampel penelitian ini terdiri dari 20 atlet ditentukan secara ordinal pairing, sehingga diperoleh 2 kelompok, masing-masing untuk mengukur kemampuan kardiorespirasi (VO2maks) menggunakan multistage. Tes power menggunakan vertical jump test, keterampilan smash menggunakan tes dari Stanley, sedangkan passing bawah menggunakan Brumbach forearms pass Wall Volley Test. Teknik analisa data menggunakan uji-t untuk memahami struktur data dalam dimensi tinggi karena melibatkan lebih dari satu variable. Hasil analisis penelitian menunjukkan bahwa variable VO2maks bahwa kelompok I meningkatkan kemampuan kardorespirasi sebesar 5,21\% atau $2.24 \mathrm{ml} / \mathrm{kg}$ bb/menit, kelompok II meningkat 2.64 atau $1.15 \mathrm{ml} / \mathrm{kg}$ $\mathrm{bb} /$ menit. Variable power atau vertical jump pada kelompok I terukur 66.20 meningkat $0.8 \mathrm{~cm}$ atau $1.2 \%$ menjadi 67.00; kelompok II terukur $69.50 \mathrm{~cm}$ meningkat sebesar $3.60 \mathrm{~cm}$ atau $5.18 \%$ menjadi $73.10 \mathrm{~cm}$. Variabel smash di kelompok I terukur 27.50 kali meningkat sebesar 0.20 atau $0.73 \%$ menjadi 27.70 kali kelompok II terukur 27.20 kali meningkat sebesar 5.8 atau $31.32 \%$ menjadi 33 kali. Variable passing bawah di kelompok I terukur 49.70 kali meningkat sebesar 0.30 atau $0.60 \%$ menjadi 50.00 kali kelompok II terukur 50.40 kali meningkat sebesar 2.0 atau $3.97 \%$ menjadi 52.40 kali. Berdasarkan hasil di atas dapat dikatakan bahwa latihan pada kelompok II yang melakukan sirkuit training di akhir latihan lebih baik dari pada kelompok I yang melakukan latihan sirkuit training di awal latihan teknik.
\end{abstract}

Kata Kunci: latihan sirkuit training, latihan teknik, kardiorespirasi

\section{Abstract}

This study aims to find out the effects of training circuit exercise at the beginning and the end of technical exercises on the cardiorespiration ability, power, and smash and underhand passing skills of the male volleyball athletes of Yuso club, Sleman. This was an experimental study using the pretest-posttest group design. The research population consisted of male volleyball athletes of Yuso Club, Sleman. The sample consisted of 20 athletes selected by ordinal pairing, and 2 groups were selected each of which was involved to measure the cardiorespiration ability $\left(\mathrm{VO}_{2}\right.$ max $)$ using the multistage. The power test used the vertical jump test, the smash skill used the Stanley test, and the underhand passing skill used the Brumbach forearms pass Wall Volley Test. The data were analized using the t-test to find out the data structure in the high dimesion because of the involvement of more than one variable. The results show that the $\mathrm{VO}_{2}$ max variable of group 1 can increase the cardiorespiration ability of $5.21 \%$ or 2.24 litres of the oxygen volume. Group 2 increase 2.64 or 1.15 litres. The variable power or vertical jump variable in group 1 is about 66.20 , increasing about $0.8 \mathrm{~cm}$ or $1.21 \%$ becoming 67.00; in group 2 it is about $69.50 \mathrm{~cm}$ increasing about $3.60 \mathrm{~cm}$ or $5.18 \%$ becoming $73.10 \mathrm{~cm}$. The variable smash in group 1 is about 27.50 times, increasing about 0.20 or $0.73 \%$ becoming 27.70 times. In group 2 it is 27.20 times increasing about 5.8 or $31.32 \%$ becoming 33 times. The underhand passing variable in group 1 is 49.70 times increasing about 0.30 or $0.60 \%$ becoming 50.00 times. In group 2 it is 50.40 times increasing about 2.0 or $3.97 \%$ becoming 52.40 times. Based on the results, it can be concluded that group II whose do circuit training exercises at the end of exercises are better than group I that do circuit training exercises at the beginning of technical exercises.

Keywords: circuit training exercise, technical exercise, cardiorespiration 


\section{Pendahuluan}

Bola voli, sebagai salah satu olah raga yang banyak digemari masyarakat sampai saat ini, tidak lepas dari kebutuhan akan kesegaran jasmani yang baik. Unsur-unsur kesegaran jasmani yang sangat penting dalam permainan bola voli adalah ketahanan kardiorespirasi dan power. Pada dasarnya, ada dua macam ketahanan kardiorespirasi, yaitu aerobik dan anaerobik. Selama permainan dengan bola voli, dibutuhkan ketahanan anaerobik untuk melakukan gerakan-gerakan eksplosif yang membutuhkan ledakan energi. Tapi untuk permainan secara umum, pola gerakan, serta waktu pemulihan, ketahanan aerobiklah yang diperlukan. Pengukuran ketahanan kardiorespirasi untuk kapasitas aerobik dapat dilakukan dengan cara mengukur konsumsi oksigen maksimal (VO2maks).

Dalam olahraga, teknik yang baik akan lebih maksimal jika didukung dengan kualitas fisik, dan kematangan emosional. Dengan dasar kondisi fisik yang baik, maka atlet akan lebih mudah menjalani latihan teknik dan mengaplikasikan selama pertandingan berlangsung. Oleh karena itu pemograman latihan fisik memerlukan aspek-aspek biomotor yang dominan dengan olahraga yang bersangkutan. Menurut Ahmadi (2007, p.65) komponen-komponen kondisi fisik meliputi kekuatan, daya tahan, daya ledak, kecepatan, daya lentur, kelincahan, koordinasi, keseimbangan, ketepatan, dan reaksi. Dalam permainan olahraga bola voli semua komponen tersebut menunjang pada penguasaan teknik dasar. Komponen biomotor ini sangat diperlukan dalam proses latihan untuk mencetak atlet. Pada kenyataannya komponen biomotor ini sering kali terabaikan dalam proses latihan, padahal komponen ini memiliki peranan yang sangat penting pada penampilan pertandingan bola voli. Seorang pemain selain harus matang dalam pukulan-pukulannya, harus mengerti taktik dan strategi, dapat membaca kekuatan lawan, dan dimana letak kelemahannya, tetapi harus tahu juga seberapa besar komponen biomotor yang dimiliki. Dalam proses latihan biomotor ini dapat dikombinasikan dengan teknik latihan pada permainan bola voli dengan tujuan untuk melakukan variasi latihan agar tidak terjadi kebosanan pada saat berlatih.

Menurut Katic, et.al (2005, p.103)

Modern volleyball is characterized by a very high outreach of of male and female volleyball players above the net and high ball velocity on jump service and spiking. a very high speed of reaction and agility are required to be able to control such balls on derve reception, especially in field defense.

Bahwa bola voli moderen ditandai dengan jangkauan yang sangat tinggi dari pemain bola voli pria dan wanita di atas kecepatan bola bersih dan tinggi pada layanan melompat dan spiking. kecepatan yang sangat tinggi dari reaksi dan kelincahan yang dibutuhkan untuk dapat mengontrol bola seperti pada penerimaan derve, terutama di pertahanan lapangan.

Menurut Langford, et.al (Shondell \& Reynaud, 2004)

In the sport of volleyball atletic conditioning progams are generally developed and initiated by coaches in order to improve performance, prevent injury, and gain the competitive edge. to achieve specificity of training, resistance exercises should closely resemble the mechanics and forces required to perform the necessary skill that occur on the court.

Bahwa dalam olahraga bola voli program pengkondisian atlet umumnya dikembangkan dan dimulai oleh pelatih dalam rangka meningkatkan kinerja, mencegah cedera, dan mendapatkan keunggulan kompetitif. Untuk mencapai spesifisitas latihan, latihan resistensi erat harus menyerupai mekanisme dan kekuatan yang dibutuhkan untuk melakukan keterampilan yang diperlukan yang terjadi di lapangan.

Sedangkan menurut Kessel (Lestari, 2008, p.82) pada permainan bola voli terdapat teknik passing bawah, passing atas, servis, block, dan smash. Teknik yang sangat dominan untuk menghasilkan point adalah teknik passing bawah, dan smash. Untuk menguasai teknik passing bawah maupun smash dengan baik dibutuhkan ketekunan dalam latihan yang terus menerus disesuaikan kemampuan atlet. Peranan pelatih sangat dibutuhkan dalam memberikan program latihan yang tepat dan berkelanjutan dengan menggunakan metode yang benar. Passing bawah dan smash sangatlah penting dalam permainan bola voli maka teknik harus dikuasai oleh semua pemain.

Untuk menghasilkan kemampuan teknik yang baik dan benar tentu perlu didukung oleh kemampuan fisik yang tinggi sehingga dalam mempelajarinya akan lebih mudah. Dalam melatih fisik tentu harus memperhatikan metode, bentuk dan prinsip-prinsip latihan. $\mathrm{Ba}$ nyak metode maupun bentuk latihan fisik dan teknik yang dapat diterapkan pelatih pada anak asuhnya. Latihan fisik bisanya menggunakan 
metode latihan sebagai berikut: sirkuit training, set blok, plyometric dan lain sebagainya. Latihan teknik juga dapat diberikan misalnya, dengan metode drill, baik sendiri, oleh teman maupun pelatih, juga bisa dengan bentuk-bentuk latihan permainan secara beregu. Dari kedua bentuk latihan fisik dan teknik tersebut dapat dikombinasikan, supaya kedua tujuan latihan di atas dapat tercapai. Latihan sirkuit training merupakan salah satu metode yang dapat diberikan pada atlet junior untuk memperbaiki kondisi fisik secara umum dimana dalam latihan sirkuit training sasaran utama dalam unsur kondisi fisik adalah kekuatan, daya tahan jantung-paru, kelentukan dan kecepatan. Pada fase transisi atau masuk fase persiapan umum perbaikan fisik umum dan teknik sangatlah diperlukan sebagai evaluasi dari periode yang lalu.

Latihan fisik dan teknik dapat dilatihkan secara bersamaan baik di awal maupun di akhir latihan. Tujuan latihan fisik dan teknik dilatihkan secara bersamaan karena pada tingkatan junior atau bahkan senior masa kompetisi sering berdekatan antara kompetisi pertama dan kompetisi berikutnya. Kenyataan jarak kompetisi dengan masa persiapan pendek. Oleh karena itu perlu metode latihan yang menggabungkan antara latihan fisik dan teknik agar kedua faktor tersebut dapat tercapai sehingga untuk melatih fisik dan teknik perlu diberikan secara bersamaan. Latihan sirkuit training di awal maupun di akhir latihan teknik dapat menjadi sebuah alternatif untuk berlatih bola voli. Latihan sirkuit training ini dilakukan dengan tujuan untuk dapat melatih kemampuan daya tahan kardiorespirasi, power, smash dan passing bawah.

Di sini peneliti berusaha mengungkap seberapa pengaruhkah latihan fisik dengan metode sirkuit training di awal latihan teknik dan latihan sirkuit training di akhir latihan teknik terhadap peningkatan kemampuan kardiorespirasi, power, keterampilan teknik smash dan passing bawah. Diharapkan atlet mendapatkan dan menguasai fisik dan teknik secara bersamaan. Juga dapat menjadikan sumbangan dalam pembinaan atlet junior dengan memberikan bentuk-bentuk latihan sehingga atlet tersebut dapat memiliki fisik dan teknik dasar yang baik dan mencapai prestasi optimal.

\section{Metode}

Penelitian ini merupakan penelitian eksperimen. Penelitian eksperimen merupakan penelitian yang dimaksudkan untuk mengetahui ada tidaknya akibat dari "sesuatu" yang dikenalkan pada subyek selidik. Dengan rancangan Pretest-Posttest Group Design. Subjek eksperimen diberikan pretest dengan tes kemampuan kardiorespirasi, power, keterampilan smash dan passing bawah. Penelitian ini dilakukan pada dua kelompok eksperimen yang diberikan perlakuan berupa latihan sirkuit training di awal latihan teknik dan latihan sirkuit training di akhir latihan teknik. tahap terakhir yaitu dilakukan posttest. Apabila pada akhirnya terdapat perbedaan antara pretest dan posttest, maka hal itu disebabkan oleh pengaruh perlakuan yang diberikan. Tempat penelitian ini dilaksanakan di klub bola voli putra Yuso Sleman Waktu penelitian dilaksanakan selama 16 kali pertemuan dengan frekuensi latihan tiga kali dalam seminggu, pada tanggal 14 Februari 2011 sampai dengan 22 April 2011. Adapun tempat penelitian untuk pretest dan posttest dan memberikan perlakuan di Hall Bulutangkis Kuningan Universitas Negeri Yogyakarta.

Populasi dalam penelitian ini adalah seluruh atlet bola voli putra di klub Yuso Sleman, dengan jumlah sampel 20 atlet dan dibedakan menjadi dua kelompok. Kelompok 1 berjumlah 10 atlet untuk latihan sirkuit traning di awal latihan teknik dan kelompok 2 juga 10 atlet untuk latihan sirkuit training di akhir latihan teknik. Populasi yang digunakan berjenis kelamin laki-laki.

Variabel Terikat

\section{Kemampuan Kadiorespirasi}

Kemampuan kardiorespirasi merupakan kemampuan paru dan jantung untuk mensuplai oksigen ke seluruh jaringana sel tubuh sebagai energi untuk dapat melakukan aktivitas fisik yang diukur menggunakan tes multistage, dengan lari bolak balik yang disesuaikan bunyi "tut" ketika sampai garis pada jarak 20 meter untuk mengukur tingkat efisiensi fungsi jantung dan paru-paru yang ditunjukan melalui pengukuran ambilan oksigen maksimum (maximum oxygen uptake) atau VO2maks.

\section{Kemampuan Power}

Power adalah hasil dari kekuatan kali kecepatan yang diukur menggunakan tes vertical jump, dengan memasukkan jari-jari salah satu tangan yang lebih dekat dengan dinding ke dalam kotak kapur. Peserta tes berdiri dengan sikap sempurna. Ukur tinggi raihan dengan cara 
menghadap ke samping dinding, kedua kaki rapat menempel pada dinding. Lengan yang dekat dengan dinding meraih ke atas setinggitingginya. Perhatikan pada saat itu kedua tumit peserta tes tidak boleh terangkat kemudian catat tinggi raihan dalam satuan $\mathrm{cm}$. Sebelum melakukan gerakan loncat tegak, peserta tes mengambil ancang-ancang dengan sikap sedikit menjauhi dinding, menekuk kedua lutut, Testi melakukan loncat tegak lurus ke atas setinggi mungkin kemudian menyentuhkan ujung jari tangannya pada mistar pada puncak raihan. Catat tinggi raihan saat meloncat. Setiap peserta tes diberi 3-5 kali kesempatan.

\section{Keterampilan Smash}

Smash merupakan bentuk serangan yang paling banyak dipergunakan dalam upaya memperoleh nilai oleh suatu tim. Smash adalah pukulan bola yang keras dari atas kebawah, jalannya bola menukik. Untuk mencapai keberhasilan yang gemilang dalam melakukan smash ini diperlukan raihan yang tinggi dan kemampuan meloncat yang tinggi. Adapun caranya dengan berdiri di belakang garis batas selama pelaksanaan tes (memukul bola) tidak boleh melewati garis tersebut selama satu menit, diberikan dua kali percobaan dengan cara melompat, jika tidak melompat tidak dihitung, karena tes ini dimaksudkan untuk mengetahui seberapa banyak testi melakukan lompatan dalam satu menit.

\section{Keterampilan Passing Bawah}

Passing dalam permainan bola voli adalah mengoperkan bola kepada teman sendiri dalam satu regu dengan suatu teknik tertentu, sebagai langkah awal untuk menyusun pola serangan kepada regu lawan. Tes ini dapat dilakukan dengan cara memvoli ke tembok sasaran yang berukuran lebar $254 \mathrm{~cm}$, dan tinggi dari lantai untuk putra $244 \mathrm{~cm}$. Setelah ada aba-aba dari petugas, Testi memvoli bola sebanyak-banyaknya dalam satu menit. Jika bola sulit dikuasai boleh ditangkap dan diteruskan kembali sampai ada aba-aba berhenti dari petugas. Setiap testi melakukan sebanyak 3 kali pelaksanaan skor akhir adalah merata dari 2 kali percobaan yang terbaik. Memvoli yang sah adalah yang masuk ke daerah sasaran, bola yang mengenai garis batas dianggap masuk. Pantulan dari lambungan atau lemparan pertama serta pantulan bola setelah mati atau ditangkap tidak dihitung.
Instrumen Penelitian dan Teknik Pengumpulan Data

Menurut Sugiyono (2011, p.148) instrumen penelitian adalah suatu alat yang digunakan mengukur fenomena alam maupun sosial yang diamati. Instrumen untuk mengukur daya tahan kardiorespirasi menggunakan tes multistage, tes power menggunakan vertical jump test, smash mengunakan tes dari Stanley dan passing bawah menggunakan forearms pass wall volley test. Tes multistage merupakan tes yang dilakukan di lapangan, sederhana namun menghasilkan suatu perkiraan yang cukup akurat tentang konsumsi maksimal untuk berbagai kegunaan atau tujuan. Tes multistage ini bertujuan untuk mengukur tingkat efisiensi fungsi kerja jantung dan paru-paru yang ditunjukkan melalui pengukuran ambilan oksigen maksimum (maximum oxygen uptake).

Intrumen untuk pengumpulan data tes power dengan menggunakan vertical jump test, bertujuan untuk mengetahui daya ledak otot tungkai, dengan cara meloncat tegak lurus ke atas. Alat yang digunakan dalam tes ini adalah mistar dengan skala cm di tempel pada dinding rata, dan tepung kapur.

Instrumen untuk keterampilan smash menggunakan tes dari Stanley. Tes keterampilan smash bertujuan untuk mengukur kemampuan smash. Alat atau perlengkapan dinding tembok berjarak $4,57 \mathrm{~m}$ dari dinding sebuah bola, stop watch, blangko penilai dan alat tulis, petugas pencatat nilai dan pengatur waktu.

Intrumen passing bawah dengan cara memvoli ke tembok sasaran yang berukuran lebar $254 \mathrm{~cm}$, dan tinggi dari lantai untuk putra $244 \mathrm{~cm}$. Perlengkapan dinding dan lantai, stop watch, bola voli, blangko penilaian dan alat-alat tulis.

\section{Teknik Analisis Data}

Teknik analisis data yang digunakan dalam penelitian ini adalah sebagai berikut: (1) Uji normalitas dilakukan untuk mengetahui apakah data mempunyai sebaran yang berdistribusi normal. Uji yang digunakan adalah uji Kolmogorov Smirnov; (2) Uji homogenitas untuk mengetahui apakah variasi-variasi dari jumlah populasi sama atau tidak (Budiyono, 2004, p.175). Uji homogenitas varian dilakukan untuk menguji kesamaan varians data kelompok eksperimen pretest dan posttest. Uji homogenitas menggunakan uji Levene's Test dengan uji $\mathrm{T}$. Rumusan yang digunakan untuk 
menguji homogenitas variansi dengan menggunakan formula uji Levene. Uji homogenitas dilakukan untuk mengetahui apakah sebaran data (variansi) kedua kelompok eksperimen tidak heterogen, dalam artian memiliki ciri-ciri atau karakteristik yang seimbang sehingga layak untuk diperbandingkan (Myers dan Well, 2003, p.160). Untuk menguji homogenitas variasi menggunakan uji levene dalam program computer SPSS. Sebaran data (variansi) kedua kelompok eksperimen dinyatakan homogen apabila hasil uji levene menunjukkan nilai signifikansi $\mathrm{p}>0,05$; 3) Uji t dilakukan untuk mengetahui apakah terdapat perbedaan variabel antara pretest dan posttest pada kelompok eksperimen. Hasil analisis dinyatakan terdapat perbedaan jika nilai signifikansi kurang dari $0,05(\mathrm{P}<0,05)$. Data yang diperoleh dari tes awal (pretest) dan tes akhir (posttest) akan dianalisis secara statistik diskpitif menggunakan uji t dengan menggunakan program SPSS komputer dengan taraf signifikansi 5\% atau 0,05. Uji $t$ ini bertujuan untuk mengetahui ada atau tidaknya pengaruh atau perbedaan latihan sirkuit training di awal latihan teknik dan latihan sirkuit training di akhir latihan teknik terhadap kemampuan kardiorespirasi, power, keterampilan smash dan passing bawah.

\section{Hasil Penelitian}

Data Hasil Penelitian

Dari proses penelitian ini diperoleh data yang relevan dengan tujuan dan hipótesis penelitian. Penyajian data dari hasil penelitian dapat berupa tabel, grafik, gambar atau bagan yang disusun sesuai tahapan pelaksanaan penelitian. Data penelitian ini didapat dari hasil pretest dan posttest yang yang diberikan sebuah perlakuan yaitu efek latihan sirkuit training yang dilaksanakan di awal dan di akhir latihan teknik.Tes awal (pretest) intesti diambil untuk mengetahui kemampuan kadiorespirasi, power, keterampilan smash dan passing bawah sebelum diberikan perlakuan. Setelah diberikan perlakuan berupa latihan sirkuit training di awal dan di akhir latihan teknik sesuai dengan dosis latihan yang tepat, maka pada tahap selanjutnya akan dilakukan tes akhir (posttest). Posttest ini bertujuan untuk mengetahui pengaruh dari perlakuan yang telah diberikan selama latihan. Adapun cara yang dilakukan untuk mengetahui kemampuan kardiorespirasi $\left(\mathrm{VO}_{2}{ }^{-}\right.$ maks) dengan tes multistage, Power melalui vertical jump test, smash menggunakan tes dari stanley, dan passing bawah menggunakan Brumbach forearms pass wall volley test.

Hasil Pretest dan Posttest Kemampuan Kardiorespirasi (VO2maks)

Tabel 1. Data Pretest dan Posttest Kemampuan Kardiorespirasi (VO2maks)

\begin{tabular}{cccccc}
\hline No & Umur & Level latihan & $\begin{array}{c}\text { Pretest VO2maks } \\
\text { (ml/Kg.bb/menit) }\end{array}$ & Level & $\begin{array}{c}\text { Posttest VO2maks } \\
\text { (ml/Kg.bb/menit) }\end{array}$ \\
\hline 1 & 19 & 11.10 & 53.2 & 11.10 & 53.2 \\
2 & 18 & 10.03 & 47.72 & 10.04 & 48.02 \\
3 & 19 & 10.02 & 47.41 & 10.08 & 49.29 \\
4 & 19 & 10.02 & 47.41 & 10.03 & 47.72 \\
5 & 19 & 10.01 & 47.11 & 10.08 & 49.24 \\
6 & 19 & 10.01 & 47.11 & 10.04 & 48.02 \\
7 & 18 & 9.02 & 43.98 & 10.01 & 47.11 \\
8 & 19 & 9.02 & 43.93 & 9.11 & 46.83 \\
9 & 19 & 9.01 & 43.66 & 9.02 & 43.98 \\
10 & 19 & 9.01 & 43.66 & 10.05 & 48.33 \\
11 & 19 & 8.07 & 42.19 & 8.07 & 41.86 \\
12 & 19 & 8.06 & 41.86 & 8.06 & 45.88 \\
13 & 18 & 8.04 & 41.2 & 9.08 & 40.87 \\
14 & 18 & 8.04 & 41.2 & 8.03 & 46.2 \\
15 & 19 & 8.03 & 40.87 & 9.09 & 42.19 \\
16 & 19 & 8.02 & 40.54 & 8.07 & 43.19 \\
17 & 19 & 8.01 & 40.21 & 8,10 & 39.87 \\
18 & 18 & 7.04 & 37.8 & 7.10 & 37.45 \\
19 & 18 & 7.03 & 37.45 & 7.03 & 37.45 \\
20 & 18 & 7.03 & 37.45 & 7.03 & \\
\hline
\end{tabular}


Data pretest kemampuan kardiorespirasi (VO2maks) sebelum dan sesudah diberikan perlakuan dapat dilihat pada Tabel 1 . Tes kemampuan kardiorespirasi ini dilakukan dengan multistage test. Data Tabel di atas adalah data pretest dan posttest setelah diberikan perlakuan latihan sirkuit training di awal maupun di akhir latihan teknik yang dilakukan dengan frekuensi latihan tiga kali dalam satu minggu dan dilakukan sebanyak 16 kali pertemuan. Selain itu dalam proses latihan harus dilakukan selama 90 menit dengan intensitas latihan $75 \%-85 \%$ denyut nadi jantung maksimal.

Dari data pretest kemampuan kardiorespirasi (VO2maks)tersebut diperoleh hasil dengan rentang skor 37 sampai 53. Adapun skor rerata pretest kemampuan kardiorespirasi sebesar 43.25, sedangkan distribusi frekuensi dari data pretest kemampuan kardiorespirasi tersebut disajikan pada Tabel 2 berikut ini.

Tabel 2. Distribusi Frekuensi Pretest Kemampuan Kardiorespirasi (VO2maks)

\begin{tabular}{cccc}
\hline No & $\begin{array}{c}\text { Kelas } \\
\text { Interval }\end{array}$ & $\begin{array}{c}\text { Frekuensi } \\
\text { Absolut }\end{array}$ & $\begin{array}{c}\text { Frekuensi } \\
\text { Relatif }(\%)\end{array}$ \\
\hline 1 & $53-60$ & 1 & 5 \\
2 & $45-52$ & 5 & 25 \\
3 & $37-44$ & 14 & 70 \\
& Jumlah & 20 & 100 \\
\hline
\end{tabular}

Berdasarkan tabel di atas dapat diketahui bahwa 14 atlet mendapat skor kemam- puan kardiorespirasi pada kelas di bawah ratarata, lima atlet pada kelas rata-rata, dan satu atlet di atas rata-rata.

Dari data posttest setelah diberikan perlakuan latihan sirkuit training di awal dan di akhir latihan teknik, data kemampuan kardiorespirasi tersebut di atas diperoleh hasil dengan rentang skor 37 sampai dengan 53. Adapun skor rerata posttest kemampuan kardiorespirasi sebesar 44, 94, sedangkan distribusi frekuensi dari data posttest kemampuan kardiorespirasi tersebut disajikan pada Tabel 3 berikut ini.

Tabel 3. Distribusi Frekuensi Posttest

Kemampuan Kardiorespirasi ( $\mathrm{VO}_{2}$ Maks)

\begin{tabular}{cccc}
\hline No & $\begin{array}{c}\text { Kelas } \\
\text { Interval }\end{array}$ & $\begin{array}{c}\text { Frekuensi } \\
\text { Absolut }\end{array}$ & $\begin{array}{c}\text { Frekuensi } \\
\text { Relatif (\%) }\end{array}$ \\
\hline 1 & $53-60$ & 1 & 5 \\
2 & $45-52$ & 10 & 50 \\
3 & $37-44$ & 9 & 45 \\
& Jumlah & 20 & 100 \\
\hline
\end{tabular}

Berdasarkan tabel di atas dapat diketahui bahwa sembilan atlet mendapat skor kemampuan kardiorespirasi di bawah rata-rata, 10 atlet pada kelas rata-rata, dan 1 atlet di atas ratarata.

Hasil Pretest dan Posttest Kemampuan Power

Tabel 4. Data Pretest dan Posttest Kemampuan Power

\begin{tabular}{cccccc}
\hline No & Umur & Tinggi raihan & Pretes power $(\mathbf{c m})$ & Tinggi raihan & Posttest power $(\mathbf{c m})$ \\
\hline 1 & 19 & 227 & 76 & 227 & 78 \\
2 & 19 & 228 & 76 & 228 & 76 \\
3 & 19 & 245 & 76 & 245 & 76 \\
4 & 19 & 236 & 75 & 236 & 77 \\
5 & 19 & 239 & 75 & 239 & 72 \\
6 & 19 & 235 & 74 & 235 & 70 \\
7 & 18 & 222 & 72 & 222 & 68 \\
8 & 19 & 224 & 71 & 224 & 76 \\
9 & 18 & 232 & 71 & 232 & 72 \\
10 & 19 & 224 & 70 & 224 & 70 \\
11 & 18 & 240 & 70 & 240 & 71 \\
12 & 19 & 232 & 65 & 232 & 75 \\
13 & 19 & 240 & 64 & 240 & 64 \\
14 & 19 & 241 & 64 & 241 & 62 \\
15 & 18 & 237 & 62 & 237 & 61 \\
16 & 18 & 234 & 62 & 234 & 61 \\
17 & 18 & 229 & 61 & 229 & 60 \\
18 & 18 & 240 & 60 & 240 & 60 \\
19 & 18 & 240 & 60 & 240 & 59 \\
20 & 19 & 236 & 59 & 236 & \\
\hline
\end{tabular}

Data pretest kemampuan power sebelum dan sesudah diberikan perlakuan dapat dilihat pada Tabel 4. Tes kemampuan power ini dilakukan dengan vertical jump test. Tabel di 
atas adalah data pretest dan posttest sebelum dan setelah diberikan perlakuan latihan sirkuit training di awal maupun di akhir latihan teknik yang dilakukan dengan frekuensi latihan tiga kali dalam satu minggu dan dilakukan sebanyak 16 kali pertemuan. Selain itu dalam proses latihan harus dilakukan selama 90 menit dengan intensitas latihan $75 \%-85 \%$ denyut nadi jantung maksimal.

Dari data pretest kemampuan power tersebut diperoleh hasil dengan rentang skor 59 sampai 76. Adapun skor rerata pretest kemampuan power sebesar 67,85 , sedangkan distribusi frekuensi dari data pretest kemampuan power tersebut disajikan pada Tabel 5 berikut ini

Tabel 5. Distribusi Frekuensi Pretest Kemampuan Power

\begin{tabular}{cccc}
\hline No & $\begin{array}{c}\text { Kelas } \\
\text { interval }\end{array}$ & $\begin{array}{c}\text { Frekuensi } \\
\text { Absolut }\end{array}$ & $\begin{array}{c}\text { Frekuensi } \\
\text { Relatif }(\%)\end{array}$ \\
\hline 1 & $75-82$ & 5 & 25 \\
2 & $67-74$ & 6 & 30 \\
3 & $59-66$ & 9 & 45 \\
& Jumlah & 20 & 100 \\
\hline
\end{tabular}

Berdasarkan tabel di atas dapat diketahui bahwa 9 atlet mendapat skor power di bawah rata-rata, 6 atlet pada kelas rata-rata, dan 5 atlet di atas rata-rata.

Tabel 6. Distribusi Frekuensi Posttest Kemampuan Power

\begin{tabular}{cccc}
\hline $\mathbf{N}$ & $\begin{array}{c}\text { Kelas } \\
\text { Interval }\end{array}$ & $\begin{array}{c}\text { Frekuensi } \\
\text { Absolut }\end{array}$ & $\begin{array}{c}\text { Frekuensi } \\
\text { Relatif }(\%)\end{array}$ \\
\hline 1 & $75-82$ & 6 & 30 \\
2 & $67-74$ & 6 & 30 \\
3 & $59-66$ & 8 & 40 \\
& Jumlah & 20 & 100 \\
\hline
\end{tabular}

Berdasarkan tabel di atas dapat diketahui bahwa 8 atlet mendapat skor power di bawah rata-rata, 6 atlet pada kelas rata-rata, dan 6 atlet di atas rata-rata.

\section{Hasil Pretest dan Posttest Keterampilan Smash}

Data pretest dan posttest keterampilan smash sebelum dan sesudah diberikan perlakuan dapat dilihat pada Tabel 7. Tes keterampilan smash ini dilakukan dengan test dari Stanley. Berikut adalah data pretest dan posttest setelah diberikan perlakuan latihan sirkuit training di awal maupun di akhir latihan teknik yang dilakukan dengan frekuensi latihan tiga kali dalam satu minggu dan dilakukan sebanyak 16 kali pertemuan. Dalam proses latihan keterampilan smash dilakukan sebelum atau setelah latihan sirkuit training dilatihkan. Data pretest dan posttest keterampilan smash dapat dilihat pada Tabel 7.

Tabel 7. Data Pretest dan Posttest Keterampilan Smash

\begin{tabular}{cccc}
\hline No & Umur & $\begin{array}{c}\text { Pretest Smash } \\
(\mathbf{c m})\end{array}$ & $\begin{array}{c}\text { Posttest Smash } \\
(\mathbf{c m})\end{array}$ \\
\hline 1 & 19 & 35 & 30 \\
2 & 19 & 35 & 30 \\
3 & 19 & 34 & 38 \\
4 & 19 & 34 & 32 \\
5 & 19 & 34 & 30 \\
6 & 19 & 32 & 29 \\
7 & 19 & 31 & 29 \\
8 & 19 & 30 & 31 \\
9 & 19 & 30 & 29 \\
10 & 19 & 30 & 35 \\
11 & 18 & 28 & 26 \\
12 & 18 & 26 & 34 \\
13 & 18 & 26 & 26 \\
14 & 19 & 24 & 24 \\
15 & 18 & 23 & 24 \\
16 & 18 & 22 & 21 \\
17 & 18 & 22 & 20 \\
18 & 19 & 20 & 26 \\
19 & 19 & 14 & 20 \\
20 & 18 & 14 & 15 \\
\hline
\end{tabular}

Dari data pretest keterampilan smash tersebut diperoleh hasil dengan rentang skor 14 sampai 35. Adapun skor rerata pretest keterampilan smash sebesar 27,35, sedangkan distribusi frekuensi dari data pretest kemampuan power tersebut disajikan pada tabel berikut ini.

Tabel 8. Distribusi Frekuensi Pretest Keterampilan Smash

\begin{tabular}{cccc}
\hline No & $\begin{array}{c}\text { Kelas } \\
\text { Interval }\end{array}$ & $\begin{array}{c}\text { Frekuensi } \\
\text { Absolut }\end{array}$ & $\begin{array}{c}\text { Frekuensi } \\
\text { Relatif (\%) }\end{array}$ \\
\hline 1 & $34-43$ & 5 & 25 \\
2 & $24-33$ & 9 & 45 \\
3 & $14-23$ & 6 & 30 \\
& Jumlah & 20 & 100 \\
\hline
\end{tabular}

Berdasarkan tabel di atas dapat diketahui bahwa 6 atlet mendapat skor smash di bawah rata-rata, 9 atlet mendapat skor kelas ratarata, 5 atlet mendapat skor di atas rata-rata.

Dari data posttest keterampilan smash tersebut diperoleh hasil dengan rentang skor 15 sampai 38. Adapun skor rerata posttest keterampilan smash sebesar 30,35, sedangkan distribusi frekuensi dari data pretest kemampuan power tersebut disajikan pada tabel berikut ini. 
Tabel 9. Distribusi Frekuensi Posttest Keterampilan Smash

\begin{tabular}{cccc}
\hline No & $\begin{array}{c}\text { Kelas } \\
\text { interval }\end{array}$ & $\begin{array}{c}\text { Frekuensi } \\
\text { absolut }\end{array}$ & $\begin{array}{c}\text { Frekuensi } \\
\text { relatif }(\%)\end{array}$ \\
\hline 1 & $35-44$ & 2 & 10 \\
2 & $25-34$ & 12 & 60 \\
3 & $15-24$ & 6 & 30 \\
& Jumlah & 20 & 100 \\
\hline
\end{tabular}

Berdasarkan tabel di atas dapat diketahui bahwa seluruh atlet mendapat skor smash di atas rata-rata, sesuai norma penilaian dari Stanley.

Hasil Pretest dan Posttest Keterampilan Passing Bawah

Data pretest dan posttest keterampilan passing bawah sebelum dan sesudah diberikan perlakuan dapat dilihat pada Tabel 10. Tes keterampilan passing bawah ini dilakukan dengan forearms pass wall volley test. Berikut adalah data pretest dan posttest sebelum dan setelah diberikan perlakuan latihan sirkuit training di awal maupun di akhir latihan teknik yang dilakukan dengan frekuensi latihan tiga kali dalam satu minggu dan dilakukan sebanyak 16 kali pertemuan. Dalam proses latihan keterampilan passing bawah dilakukan sebelum atau setelah latihan sirkuit training dilatihkan. Data pretest dan posttest keterampilan passing bawah dapat dilihat pada tabel berikut ini.

Tabel 10. Data Pretest dan Posttest Keterampilan Passing Bawah

\begin{tabular}{cccc}
\hline No & Umur & $\begin{array}{c}\text { Pretest Passing } \\
\text { bawah (cm) }\end{array}$ & $\begin{array}{c}\text { Posttest Passing } \\
\text { bawah (cm) }\end{array}$ \\
\hline 1 & 19 & 55 & 53 \\
2 & 19 & 54 & 55 \\
3 & 19 & 53 & 53 \\
4 & 19 & 52 & 52 \\
5 & 19 & 51 & 52 \\
6 & 19 & 50 & 53 \\
7 & 19 & 50 & 50 \\
8 & 18 & 50 & 50 \\
9 & 19 & 50 & 49 \\
10 & 18 & 50 & 49 \\
11 & 18 & 49 & 52 \\
12 & 18 & 49 & 50 \\
13 & 19 & 49 & 50 \\
14 & 19 & 49 & 50 \\
15 & 19 & 49 & 49 \\
16 & 19 & 49 & 49 \\
17 & 19 & 49 & 47 \\
18 & 18 & 47 & 49 \\
19 & 18 & 46 & 47 \\
20 & 18 & 46 & 46 \\
\hline & & &
\end{tabular}

Dari data pretest keterampilan passing bawah tersebut diperoleh hasil dengan rentang skor 46 sampai 55. Adapun skor rerata pretest keterampilan smash sebesar 50,05, sedangkan distribusi frekuensi dari data pretest keterampilan passing bawah tersebut disajikan pada tabel berikut ini.

Tabel 11. Distribusi Frekuensi Pretest Keterampilan Passing Bawah

\begin{tabular}{cccc}
\hline No & $\begin{array}{c}\text { Kelas } \\
\text { Interval }\end{array}$ & $\begin{array}{c}\text { Frekuensi } \\
\text { Absolut }\end{array}$ & $\begin{array}{c}\text { Frekuensi } \\
\text { Relatif (\%) }\end{array}$ \\
\hline 1 & $62-69$ & 1 & 5 \\
2 & $54-61$ & 1 & 5 \\
3 & $46-53$ & 18 & 90 \\
& Jumlah & 20 & 100 \\
\hline
\end{tabular}

Berdasarkan tabel di atas dapat diketahui bahwa 18 atlet mendapat skor passing bawah pada kelas rata-rata, dan 2 atlet di atas ratarata.

Dari data posttest keterampilan passing bawah tersebut diperoleh hasil dengan rentang skor 46 sampai 55. Adapun skor rerata pretest keterampilan smash sebesar 51,02, sedangkan distribusi frekuensi dari data pretest keterampilan passing bawah tersebut disajikan pada tabel berikut ini.

Tabel 12. Distribusi Frekuensi Posttest Keterampilan Passing Bawah

\begin{tabular}{cccc}
\hline No & $\begin{array}{c}\text { Kelas } \\
\text { Interval }\end{array}$ & $\begin{array}{c}\text { Frekuensi } \\
\text { Absolut }\end{array}$ & $\begin{array}{c}\text { Frekuensi } \\
\text { Relatif }(\%)\end{array}$ \\
\hline 1 & $54-57$ & 1 & 5 \\
2 & $50-53$ & 11 & 55 \\
3 & $46-49$ & 8 & 40 \\
& Jumlah & 20 & 100 \\
\hline
\end{tabular}

Berdasarkan tabel di atas dapat diketahui bahwa 8 atlet mendapat skor passing bawah pada kelas rata-rata, dan 12 atlet di atas ratarata.

Tabel 13. Hasil Uji Normalitas

\begin{tabular}{cccccc}
\hline \multirow{2}{*}{ Kel } & \multirow{2}{*}{ Variabel } & \multicolumn{2}{c}{ Pre } & \multicolumn{2}{c}{ Post } \\
\cline { 3 - 6 } & & k-s & P & k-s & P \\
\hline \multirow{4}{*}{ I } & Vo2Max & 0.607 & 0.855 & 0.515 & 0.953 \\
& V-Jump & 0.761 & 0.609 & 0.823 & 0.507 \\
& Smash & 0.460 & 0.984 & 0.804 & 0.537 \\
& Pass & 0.572 & 0.899 & 0.632 & 0.819 \\
& Bawah & 0.572 & \\
& Vo2Max & 0.858 & 0.453 & 0.589 & 0.879 \\
& V-Jump & 0.774 & 0.587 & 1.181 & 0.123 \\
II & Smash & 0.528 & 0.944 & 0.653 & 0.787 \\
& Pass & 0.858 & 0.453 & 0.589 & 0.879 \\
\cline { 2 - 6 } & Bawah & & &
\end{tabular}

Sumber : Hasil pengolahan data primer 
Distribusi data dievaluasi dengan uji kolmogorov Smirnov, hasil pengujian mendapatkan koefesien KS sebesar 0.607 dengan probabilitas sebesar 0.855 untuk VO2maks kelompok pretest. Hasil $\mathrm{p}>0.05$ menandakan data berdistribusi normal. Demikian juga untuk variabel power dan keterampilan, memiliki $p>0.05$ berarti normal. Dari uraian di atas bahwa variabel semuanya normal.

Hasil uji $\mathrm{F}$ untuk mengevaluasi kesamaan varian VO2maks kedua kelompok sebelum perlakuan diperoleh F-hitung 0.103 dengan probabilitas sebesar 0.752 . Perolehan $\mathrm{p}>0.05$ menandakan kapasitas intake paru mereka (kelompok) adalah homogen. Demikian juga untuk power dan keterampilan, dikedua kelompok homogen.
Tabel 14. Hasil Uji Homogenitas

\begin{tabular}{ccc}
\hline Variabel & F-hitung & P \\
\hline Vo2Max & 0.103 & 0.752 \\
V-Jump & 3.201 & 0.090 \\
Smash & 0.007 & 0.932 \\
Pass Bawah & 0.045 & 0.835 \\
\hline
\end{tabular}

Sumber : Hasil pengolahan data primer

Hasil Uji t

Uji t dilakukan untuk mengetahui apakah terdapat perbedaan VO2maks, power, keterampilan antara pretest dan posttest pada kelompok yang berlatih sirkuit training di awal dan di akhir latihan teknik. Hasil analisis dinyatakan terdapat perbedaan jika nilai signifikansi kurang dari 0,05 (P<0,05). Secara statistik perbedaan tersebut dievaluasi dengan uji $t$ untuk melihat kebermaknaannya.

Tabel 15. Hasil Uji t Pre Melawan Post

\begin{tabular}{|c|c|c|c|c|c|c|c|c|}
\hline \multirow{2}{*}{ Aspek } & \multirow{2}{*}{ Variabel } & \multirow{2}{*}{ Kel. } & \multicolumn{3}{|c|}{ Lat.di Awal (Kel I) } & \multicolumn{3}{|c|}{ Lat. di Akhir (Kel II) } \\
\hline & & & Rerata & $\mathbf{t}$ & $\mathbf{p}$ & Rerata & $\mathbf{T}$ & $\mathbf{p}$ \\
\hline \multirow[t]{2}{*}{ Kardiorespirasi } & VO2maks & Pre (pra Latihan) & 42.93 & & & 43.57 & & \\
\hline & & Post (pasca latihan) & 45.17 & 3.384 & 0.008 & 44.72 & 2.621 & 0.028 \\
\hline \multirow[t]{2}{*}{ Power } & V-Jump & Pre (pra Latihan) & 66.20 & & & 69.50 & & \\
\hline & & Post (pasca latihan) & 67.00 & 2.753 & 0.022 & 73.10 & 3.515 & 0.007 \\
\hline \multirow[t]{4}{*}{ KetramPilan } & Smash & Pre (pra Latihan) & 27.50 & & & 27.20 & & \\
\hline & & Post (pasca latihan) & 27.70 & 0.176 & 0.864 & 33.00 & 4.990 & 0.001 \\
\hline & Pass & Pre (pra Latihan) & 49.70 & & & 50.40 & & \\
\hline & Bawah & Post (pasca latihan) & 50.00 & 0.818 & 0.434 & 52.40 & 5.477 & 0.000 \\
\hline
\end{tabular}

Sumber : Hasil pengolahan data primer

Rangkuman dalam tabel di atas memperlihatkan tidak semua perlakuan mampu meningkatkan secara bermakna. Sirkuit training yang dilaksakan di awal latihan teknik memberikan manfaat bermakna terhadap peningkatan kemampuan kardirespirasi (VO2maks) dan Power, namun tidak bermakna terhadap keterampilan (smash dan passing bawah).

Terlihat untuk $\mathrm{VO}_{2}$ maks menghasilkan t-hitung sebesar 3.384 dengan probabilitas 0.008 , dan terhadap Vertical jump menghasilkan t-hitung sebesar 2.753 dengan probabilitas 0.022 . keduanya memiliki $p \leq 0.05$ menandakan signifikan. Sedangkan untuk power dan keterampilan tidak signifikan.

Kelompok II yang melakukan sirkuit training di akhir latihan teknik terlihat mengalami perubahan bermakna pada semua variabel. Terlihat $\mathrm{VO}_{2}$ maks, Vertical jump, smash dan passing bawah memiliki probabilitas kurang dari 0.05. Hasil ini menjelaskan bahwa latihan di akhir mampu meningkatkan semua aspek yang diukur.

Kemudian untuk kelompok I di awal latihan, dengan variable smash menghasilkan thitung sebesar 0.176 dengan probabilitas 0.864 , dan terhadap passing bawah menghasilkan thitung sebesar 0.818 dengan probabilitas 0.434 . keduanya memiliki $p>0.05$ menandakan signifikan.

Kelompok II yang melakukan sirkuit training di akhir latihan teknik terlihat mengalami perubahan bermakna pada semua variabel. Terlihat VO2maks, power, smash dan passing bawah memiliki probabilitas kurang dari 0.05. Hasil ini menjelaskan bahwa latihan di akhir mampu meningkatkan semua aspek yang diukur. 
Tabel 16. Hasil Uji t Latihan di Awal Melawan di Akhir

\begin{tabular}{lllcccccc}
\hline \multirow{2}{*}{ Aspek } & \multirow{2}{*}{ Variabel } & \multicolumn{2}{c}{ Kel. } & \multicolumn{3}{c}{ Pre Test } & \multicolumn{3}{c}{ Post Test } \\
\cline { 3 - 8 } & & & Rerata & t & p & Rerata & t & P \\
\hline Kardiorespirasi & Vo2Max & Lat. di awal (kel I) & 43.57 & -0.34 & 0.738 & 44.72 & 0.24 & 0.816 \\
Power & & Lat. di akhir (kel II) & 42.93 & & & 45.17 & & \\
\multirow{3}{*}{ Ketrampilan } & V-Jump & Lat. di awal (kel I) & 66.20 & 1.32 & 0.202 & 67.00 & 2.25 & 0.037 \\
& \multirow{2}{*}{ Smash } & Lat. di akhir (kel II) & 69.50 & & & 73.10 & & \\
& Lat. di awal (kel I) & 27.50 & -0.10 & 0.920 & 27.70 & 2.44 & 0.025 \\
& Passing & Lat. di akhir (kel II) & 27.20 & & & 33.00 & & \\
& Lawah & Lat. di awal (kel I) & 49.70 & 0.69 & 0.499 & 50.00 & 2.39 & 0.028 \\
\hline
\end{tabular}

Sumber : Hasil pengolahan data primer

Selain untuk melihat kebermaknaan latihan sirkuit training, dikaji juga komparasi antar kedua waktu latihan tersebut. Rangkuman dalam tabel di atas memperlihatkan semua hasil uji t sebelum mendapat perlakuan (pretest) memiliki probabilitas lebih dari 0.05 . Seperti pada kardiorespirasi yang di ukur melalui VO2maks, diperoleh t-hitung sebesar -0.34 dengan probabilitas $(\mathrm{p})$ sebesar 0.738. $\mathrm{p}>0.05$ menandakan perbedaannya tidak signifikan, berarti meskipun terlihat ada variasi skor rerata namun tidak dapat dikatakan sebagai perbedaan yang bermakna.

Perbedaan yang tidak signifikan tersebut menguatkan hasil homogenitas sebelumnya bahwa, sebagai pemain bola voli secara rata- rata dapat dikatakan sama dalam kardiorepirasi, power dan keterampilan. Kemudian setelah menjalani sirkuit training (perlakuan) mengalami perubahan signifikan untuk power dan keterampilan, namun tidak signifikan untuk kardiorespirasi. Terlihat dalam tabel di atas thitung VO2maks posttest sebesar 0.24 dengan $\mathrm{p}>0.05$ yaitu 0.816. Sedangkan untuk power (Vertical jump) t-hitung sebesar 2.25 dengan probabilitas sebesar 0.037 , hasil $\mathrm{p} \leq 0.05$ menandakan signifikan. Demikian juga untuk keterampilan (smash dan passing bawah) terlihat memiliki $\mathrm{p} \leq 0.05$, menandakan signifikan.

Hasil uji t untuk perubahan dari pretest ke posttest dapat dilihat pada tabel berikut

Tabel 17. Hasil Uji t Perubahan dari Pretest ke Posttest

\begin{tabular}{|c|c|c|c|c|c|}
\hline Aspek & Variabel & Kelompok & Rerata Perubahan & $\mathbf{t}$ & $\mathbf{P}$ \\
\hline \multirow{2}{*}{ Kardiorespirasi } & Vo2Max & Lat. di awal (Kel I) & 1.15 & 1.37 & 0.187 \\
\hline & & Lat. di akhir (Kel II) & 2.24 & & \\
\hline \multirow[t]{2}{*}{ Power } & V-Jump & Lat. di awal (Kel I) & 0.80 & 2.63 & 0.017 \\
\hline & & Lat. di akhir (Kel II) & 3.60 & & \\
\hline \multirow[t]{4}{*}{ Ketrampilan } & Smash & Lat. di awal (Kel I) & 0.20 & 3.45 & 0.003 \\
\hline & & Lat. di akhir (Kel II) & 5.80 & & \\
\hline & Pass Bawah & Lat. di awal (Kel I) & 0.30 & 3.29 & 0.004 \\
\hline & & Lat. di akhir (Kel II) & 2.00 & & \\
\hline
\end{tabular}

Sumber : Hasil pengolahan data primer

Besar perubahan (peningkatan atau penurunan) yang terjadi dikelompok I dan II juga dievaluasi kebermaknaannya, sehingga dapat dijelaskan tidak saja dari hasil akhir latihan, melainkan juga dari proses (perubahan) yang terjadi. Terlihat dalam tabel di atas pengujian perbedaan perubahan VO2maks dikedua kelompok mendapatkan t-hitung sebesar 1.37 dengan probabilitas 0.187 , Hasil $\mathrm{p}>0.05$ menandakan tidak signifikan, berarti tidak terjadi perubahan yang bermakna antara kelompok yang latihan di awal di akhir.

Variabel lainnya yang menjelaskan power dan keterampilan terlihat memiliki pro- babilitas kurang dari 0.05, menandakan signifikan. Berarti peningkatan yang terjadi setelah menjalani latihan di awal dan akhir adalah bermakna.

Uji Hipotesis

Setelah dilakukan uji normalitas sebagai prasyarat analisa, selanjutnya dilakukan pengujian hipotesis rnenggunakan uji t sebagai berikut: 
Latihan Sirkuit Training di Awal Latihan Teknik dapat Meningkatkan Kemampuan Kardiorespirasi, Power, Keterampilan Smash dan Passing Bawah pada Atlet Bola Voli Putra Yuso Sleman

Berdasarkan hasil uji t mengenai perbedaan Latihan sirkuit training di awal latihan teknik dapat meningkatkan kemampuan kardiorespirasi, power, keterampilan smash dan passing bawah pada atlet bola voli putra Yuso Sleman,secara keseluruhan dapat ditunjukkan pada Tabel 17 di atas. Hasil analisis terhadap kemampuan kardiorespirasi (VO2maks) menghasilkan sebesar 3.384 dengan probabilitas $\mathrm{p}=$ $0.008<0,05$. Kemudian vertical jump atau power menghasilkan t-hitung 2.753 dengan probabilitas $\mathrm{p}=0.022$. keduanya memiliki $\mathrm{p} \leq 0.05$ menandakan signifikan. Artinya, hipotesis nol (Ho) yang menyatakan tidak ada perbedaan kemampuan kardiorespirasi antara pretest dan posttest ditolak. Dengan kata lain dapat dinyatakan bahwa terdapat perbedaan yang signifikan antara pretest dan posttest. Berdasarkan analisis tersebut ternyata kemampuan kardiorespirasi posttest lebih baik dari pada pretest. Hal ini berarti bahwa hipotesis penelitian yang menyatakan bahwa latihan sirkuit training di awal latihan teknik dapat meningkatkan kemampuan kardiorespirasi dan power pada atlet bola voli putra klub Yuso Sleman. Sedangkan smash menghasilkan t-hitung 0.176 dengan probabilitas 0.854 , dan passing bawah menghasilkan t-hitung 0.818 dan probabilitas 0.434 , keduanya memiliki $\mathrm{p}>0.05$, menandakan keterampilan smash dan passing bawah tidak signifikan. Hasil ini menjelaskan bahwa latihan di awal hanya mampu meningkatkan kardiorespirasi dan power, hipotesis keduanya diterima, tetapi tidak bermakna terhadap keterampilan smash dan passing bawah, sehingga hipotesis ditolak. Hal ini berarti bahwa hipotesis penelitian yang menyatakan bahwa latihan sirkuit training di awal latihan teknik dapat meningkatkan kemampuan keterampilan smash dan passing bawah pada atlet bola voli putra klub Yuso Sleman tidak teruji.

Latihan Sirkuit Trainingdi Akhir Latihan Teknik dapat Meningkatkan Kemampuan Kardiorespirasi, Power, Keterampilan Smash dan Passing Bawah pada Atlet Bola Voli Putra Yuso Sleman

Berdasarkan hasil uji t mengenai perbedaan latihan sirkuit training di akhir latihan teknik dapat meningkatkan kemampuan kardiorespirasi, power, keterampilan smash dan passing bawah pada atlet bola voli putra Yuso Sleman,secara keseluruhan dapat ditunjukkan pada Tabel 17 di atas menghasilkan, VO2maks sebesar 2.621 dengan probabilitas 0.028 , vertical jump atau power menghasilkan t-hitung 3.515 dengan probabilitas 0.007 , smash menghasilkan t-hitung 4.990 dengan probabilitas 0.001, dan pasing bawah menghasilakan t-hitung 5.477 dan probabilitas 0.000dari keempat variable memiliki $\mathrm{p}<0.05$ menandakan signifikan atau hipotesis diterima. Artinya, hipotesis nol (Ho) yang menyatakan tidak ada perbedaan kemampuan kardiorespirasi, power, keterampilan smash dan passing bawah antara pretest dan posttest ditolak. Dengan kata lain dapat dinyatakan bahwa terdapat perbedaan yang signifikan antara pretest dan posttest. Berdasarkan analisis tersebut ternyata kemampuan kardiorespirasi, power, keterampilan smash dan passing bawah posttest lebih baik dari pada pretest. Hal ini berarti bahwa hipotesis penelitian yang menyatakan bahwa latihan sirkuit training di akhir latihan teknik dapat meningkatkan kemampuan kardiorespirasi, power, keterampilan smash dan passing bawah pada atlet bola voli putra klub Yuso Sleman telah teruji.

\section{Latihan Sirkuit Training di Akhir Teknik Lebih Baik dari pada Latihan Sirkuit Training di Awal Latihan Teknik terhadap Kemampuan Kardiorespirasi, Power, Keterampilan Smash dan Passing Bawah pada Atlet Bola Voli Putra Yuso Sleman}

Ada perbedaan efektifitas antara latihan sirkuit training di awal dan di akhir latihan teknik tehadap kemampuan kardiorespirasi, power, keterampilan smash dan passing bawah pada atlet bola voli putra Yuso Sleman. Hasil perhitungan statistik di atas menunjukkan setelah dilakukan perlakuan atau posttest. Bila dilihat dari perbedaan rerata, hasil perhitungan menunjukkan bahwa latihan di awal rata-rata pretest $=46.742$, posttest $=47.355$, sehingga mempunyai perbedaan rerata $=0.613$, sedangkan latihan sirkuit training di akhir latihan teknik rata-rata pretest $=47.507$, posttest $=50$. 917, sehingga mempunyai perbedaan rerata $=$ 3.410. Hasil perhitungan rerata ini menunjukkan bahwa latihan sirkuit training di akhir latihan teknik memiliki perbedaan rerata lebih besar dari latihan sirkuit training di awal latihan teknik. Dengan demikian dapat diartikan 
bahwa latihan sirkuit training di akhir latihan teknik lebih efektif dari pada latihan sirkuit training di awal latihan teknik terhadap kemampuan kardiorespirasi, power, keterampilan smash dan passing bawah pada atlet bola voli putra Yuso Sleman telah teruji.

\section{Pembahasan}

\section{Daya Tahan Kardiorespirasi (VO2maks)}

Penelitian yang telah dilakukan menunjukkan bahwa daya tahan kardiorespirasi dari 20 atlet dengan jenis kelamin laki-laki, pada atlet bola voli putra Yuso Sleman menunjukkan bahwa kemampuan kardiorespirasi mengalami peningkatan yang signifikan. Hal ini dapat dilihat dari taraf signifikansi yang kurang dari 0,05 yaitu 0,000 . Fakta empiris dari hasil penelitian menunjukkan rata-rata pada kelompok I dan kelompok II baik pretest maupun posttest pada variable kemampuan kardiorespirasi (VO2maks) mengalami peningkatan. Berdasarkan pada uraian di atas, pengaruh latihan sirkuit training di awal dan di akhir latihan teknik dapat ditarik kesimpulan pada penelitian ini bahwa berpengaruh terhadap kemampuan kardiorespirasi (VO2maks), karena dalam latihan sirkuit training di awal maupun di akhir latihan teknik sangat berhubungan dengan penggunaan oksigen yang melibatkan fungsi kardiorespirasi. Latihan tersebut adalah melakukan bentuk-bentuk latihan sirkuit training dilanjutkan dengan latihan teknik yang divariasikan. Meningkatnya kemampuan kardiorespirasi juga disebabkan oleh beban atau takaran latihan dilakukan sesuai dengan dosis latihan yang tepat.

Power

Sama seperti pengukuran kardiorespirasi yang diukur dua kali, vertical jump juga dilihat antara sebelum dan sesudah latihan sirkuit training menunjukkan rata-rata pada kelompok I dan kelompok II baik pretest maupun posttest pada variabel kemampuan power mengalami peningkatan. Meningkatnya hasil pengukuran di posttest menjelaskan bahwa latihan sirkuit training dapat meningkatkan Vertical jump atau power. Sedangkan lebih tingginya peningkatan di kelompok II menjelaskan bahwa latihan sirkuit trining di akhir latihan teknik memberikan manfaat lebih tinggi.

Sirkuit training di akhir latihan teknik (kelompok I dan II) juga membantu meningkatkan power secara lebih individu. Terlihat kelompok ini memiliki simpangan baku lebih besar, menunjukan keragaman power yang lebih tinggi. Keragaman ini mengartikan beberapa individu mengalami peningkatan lebih besar, berarti sirkuit training mampu mengoptimalkan karena pada saat latihan sirkut trainingbentuk-bentuk latihannya bersifat plyometrik atau gerakan yang cepat.Meningkatnya kemampuan power juga disebabkan oleh beban atau takaran latihan dilakukan sesuai dengan dosis latihan yang tepat.

\section{Smash}

Kemampuan atlet melakukan smash dengan benar mereprsentasikan penguasaan berbagai keterampilan dalam smash. Dalam pengertian ini maka jumlah smash yang dapat dilakukan dalam waktu tertentu menggambarkan tingkat keterampilan mereka.

Peningkatan lebih besar di kelompok II menjelaskan bahwa latihan sirkuit training di akhir latihan teknik dapat meningkatkan keterampilan smash lebih baik dibandingkan yang melakukannya di awal latihan teknik. Karena ketika latihan teknik smash atlet belum mengalami kelelahan fisik yang berarti sebab latihan sirkuit training diberikan di akhir latihan teknik. Namun bila dilihat dari keragaman keterampilan smash antarindividu, terlihat relatif sama antara peningkatan di kelompok I dan II. Fakta ini menjelaskan peningkatan keterampilan relatif homogen antar individunya.

\section{Passing Bawah}

Keterampilan penting lain bagi pemain bola voli adalah passing bawah. Seperti smash, mereka yang dapat melakukan passing bawah dengan benar berarti menguasai sejumlah keterampilan di dalamnya. Jumlah passing bawah yang dapat dilakukan dengan benar selama waktu tertentu merepresentasikan tingkat keterampilan. Hasil pengukuran menunjukan jumlah passing bawah benar per menit pada kelompok I dan kelompok II baik pretest maupun posttest mengalami peningkatan.

Peningkatan lebih besar di kelompok II menjelaskan bahwa latihan sirkuit training di akhir latihan teknik dapat meningkatkan keterampilan passing bawah lebih baik dibandingkan yang melakukannya di awal latihan teknik. Dilihat dari keragaman keterampilan passing bawah antarindividu juga terlihat perbedaan yang cukup. Fakta ini menjelaskan sirkuit training di akhir latihan teknik lebih mampu meningkatkan keterampilan passing bawah dan dapat mengoptimalkan keunggulan indivi- 
du. Karena ketika latihan teknik passing bawah atlet belum mengalami kelelahan fisik yang berarti sebab latihan sirkuit training diberikan di akhir latihan teknik sehingga konsentrasi dan reaksi dalam melakukan gerakan-gerakan dalam latihan teknik masih baik.

Dari uraian pembahasan mengenai pengaruh latihan sirkuit training di awal dan di akhir latihan teknik terhadap kemampuan kardiorespirasi, power, smash dan passing bawah dapat disimpulkan bahwa latihan sirkuit training di awal latihan teknik tidak menunjukan efek bermakna terhadap peningkatan terhadap kardiorespirasi dan power, keterampilan smash dan passing bawah. Sedangkan terhadap smash dan passing bawah memberikan efek yang bermakna. Fakta ini menjelaskan tanpa mengetahui relevansi latihan sirkuit training dengan teknik yang sedang diasah maka tidak akan memberikan hasil maksimal.

Latihan sirkuit training di awal latihan teknik ibarat melakukan latihan tanpa mengetahui maksudnya. Sehingga memungkinkan subjek (atlet) kurang memahami apalagi merasakan target latihan. Meskipun secara verbal target ini dapat dikomunikasikan, namun penjelasan secara verbal terkadang tidak dapat mencapai maksud dari suatu skill (motorik), sebaliknya praktek akan langsung merasakan maksudnya. Oleh sebab itu latihan sirkuit training di akhir latihan teknik memberikan peningkatan bermakna.

Terhadap efek peningkatan non keterampilan yaitu kardiorespirasi dan power, latihan di awal dan akhir teknik sama-sama memberikan peningkatan signifikan. Manfaat ini tetap dapat diraih karena latihan sirkuit training seperti juga olah raga pada umumnya ada manfaat secara umum dari meningkatkan kebugaran dan kesiapan otot (power).

Hasil penelitian ini menemukan karakter berbeda dari kardiorespirasi dibandingkan dengan power keterampilan smash dan passing bawah. Tampak bahwa latihan sirkuit training di awal dan di akhir latihan teknik sama-sama meningkatkan kardiorespirasi dengan besar peningkatan yang sama. Hasil ini berbeda dengan power dan Keterampilan, dimana untuk keduanya ini latihan sirkuit training di akhir latihan teknik memberikan hasil lebih baik dibandingan di awal latihan teknik.

Hasil sama baik terhadap kardiorespirasi terkait dengan kapasitas paru yang pada dasarnya relatif sama setelah mencapai kemampuan optimumnya. Berbeda dengan power dan keterampilan yang dapat terus ditingkatkan dalam range yang panjang dan berbeda-beda.

Karakteristik tersebut juga menguatkan kembali bahwa latihan sirkuit training di akhir latihan teknik dapat dimengerti lebih baik. Karena subjek mengetahui lebih pasti dari maksud latihan. Sehingga masing-masing dapat mengkondisikan dirinya untuk merelevansikan latihan training dengan teknik.

Dilandasi oleh suatu tujuan yaitu agar para pendidik, terutama para pelatih mau dan mampu meningkatkan kinerjanya sebagai upaya peningkatan kualitas pendidikan atau pelatihan sesuai yang diamanatkan oleh UndangUndang. Artinya disamping pelatih memahami bidang tugas dan kewajibannya, tetapi lebih ditekankan pada pelatih memiliki kemampuan memanfaatkan perkembangan yang terjadi dalam ilmu pengetahuan dan teknologi.

\section{Simpulan dan Saran}

Simpulan

Setelah dilakukan pengolahan data dan analisis mengenai pengaruh latihan sirkuit training di awal dan di akhir latihan teknik terhadap kemampuan kardiorespirasi, power, keterampilan smash dan passing bawah maka temuan yang telah diuraikan dalam bab sebelumnya menunjukan pengaruh latihan sirkuit training dan perbedaan manfaatnya antara yang berlatih di awal dan di akhir latihan teknik. Berdasarkan hasil-hasil tersebut disimpulkan: Latihan sirkuit training di awal latihan teknik memberikan pengaruh positif dan signifikan terhadap kardiorespirasi dan power pemain bola voli, namun tidak berpengaruh terhadap keterampilan smash maupun passing bawah, latihan sirkuit training di akhir latihan teknik memberikan pengaruh positif dan signifikan terhadap kardiorespirasi, power, smash dan passing bawah pada pemain bola voli. Untuk meningkatkan kemampuan kardiorespirasi dan power mengunakan metode sirkuit training lebih baik diberikan setelah latihan teknik.

Sasan

Kesimpulan di atas mengisyaratkan manfaat sirkuit training di akhir latihan teknik memberikan pengaruh lebih besar terhadap kardiorespirasi, power dan keterampilan pemain bola voli.Temuan ini perlu diperhatikan oleh para guru olah raga atau pelatih bola voli. Meskipun tidak dapat untuk mengesampingkan faktor lain yang diduga memberikan andil, pa- 
ling tidak kesimpulan tersebut dapat diterapkan secara terbatas.

Kesimpulan tersebut juga menjadi masukan berharga agar guru atau pelatih dapat mengembangkan setiap sirkuit training.Dapat dimodifikasi sesuai dengan tujuannya agar mampu memaksimalkan manfaat dari sirkuit training, bahkan membuka kemungkinan dilakukannya pencampuran yang sesuai dengan karakteristik pemain.

\section{Daftar Pustaka}

Cole, D.L \& Kessel J. (2007). Coaching youth volleyball.(Novi Lestari Terjemahan). Klaten: PT Intan Sejati. Buku asli diterbitkan tahun 2008.

Langford, G. A, et al. (2004). Effects of singleleg resistance training on measurement of jumping performance in NCCAA division II Women Volleyball
Players. Valdosta State University, Georgia (USA).

Myers, J.L. \& Arnold, D.W. (2003). Research design and statistical analysis. New Jersey: Laurence Relbaum Associates, Inc. Publishers.

Ahmadi, Nuril. (2007). Panduan olahraga bolavoli. Surakarta: Era Pustaka Utama.

Ratko, K, et.al. (2005). Motor structures in female volleyball players aged 14-17 according to technique quality and performance. Faculty of Natural Sciences, Mathematics and Kinesiology, University of Split, Split, Croatia.

Sugiyono. (2011). Metode penelitian pendidikan pendekatan kuantitatif, kualitatif dan $R \& D$. Bandung: Alfabeta Bandung. 